\title{
Subconjuctival Adult Bancroftian Filarial Worm A Case Report
}

\author{
${ }^{1}$ Dr. Mukta Khaparkuntikar, ${ }^{2}$ Dr A. S .Damle. ${ }^{3}$ Dr Jyoti Iravane, , ${ }^{4}$ Dr.Bhakare \\ $\mathrm{J},{ }^{5}$ Dr. Ostwal.k \\ (Dept. Of Microbiology, GMC, and Aurangabad).
}

\begin{abstract}
We are reporting a case of 60 yr old female from non endemic, resident of Pahur Tq. Jamner, Dist. Aurangabad. She complained of abnormal sensation of some moving in right eye intermittently. The size of the eye was gradually becoming small. Also the patient had redness and watering of eye. But there was no pain. These symptoms were present since 3 years. She was treated with antibiotic and analgesic eye drops, with no relief. on opthalmic examination there was subconjuctival worm which was removed surgically. The worm was identified as W. bancrofti \& properly treated. Live adult worm in subconjuctiva of eye is uncommon in India. However, ophthalmologists should be aware of this clinical manifestation and go for a proper examination and identification of the worm.
\end{abstract}

Keywords: Subconjuctival worm, W.bancrofti, ocular infestation.

\section{Case :}

We are reporting a case of $60 \mathrm{yr}$ old female, resident of Pahur Tq. Jamner, Dist. Aurangabad. She complained of abnormal sensation of some movement in right eye intermittently. The size of the eye was gradually becoming small. Also the patient had redness and watering of eye. But there was no pain. These symptoms were present since 3 years. She was treated with antibiotic and analgesic eye drops, with no relief.

On ophthalmologic examination: A small (3-4 mm) circumscribed, congested tumour-like elevation was noted on the outer side of the temporal limbus of the right eye. While observing the lesion for a few minutes, some movement was noted under the congested conjunctiva. A white thread-like worm appeared to be moving under swelling. The ophthalmologic examination was otherwise normal including corrected visual acuity in both eyes.

Lab Test: Patient's serum was negative for antigen and antibody for filarial worm as per report from MGIMS, Sevagram.

Surgical Treatment: Under subconjunctival infiltration anaesthesia, the live worm was removed carefully. No other treatment was required.

\section{Confirmation:}

The live worm was sent in normal saline for identification. The adult nematode appeared as a threadlike, milky white worm with a cylindrical body measuring $12 \mathrm{~cm}$ in length and $0.5 \mathrm{~mm}$ diameter. The tail was tapering and head was terminating in a slightly rounded swelling (Figure2, 3). It appeared to be a female filarial worm.

The worm was W. bancrofti, as identified in PGIMER, Chandigarh.

Treatment given-

Diethycarbamazine $(6 \mathrm{mg} / \mathrm{kg} /$ day for $2-3 \mathrm{wks})$

Purpose of reporting this case was Ocular filariasis due to W. bancrofti is very rare. It can present in an otherwise asymptomatic patient without any constitutional symptoms for that Careful examination, prompt diagnosis, and early treatment can reduce ocular morbidity 
Fig 1 (tail end of parasite)
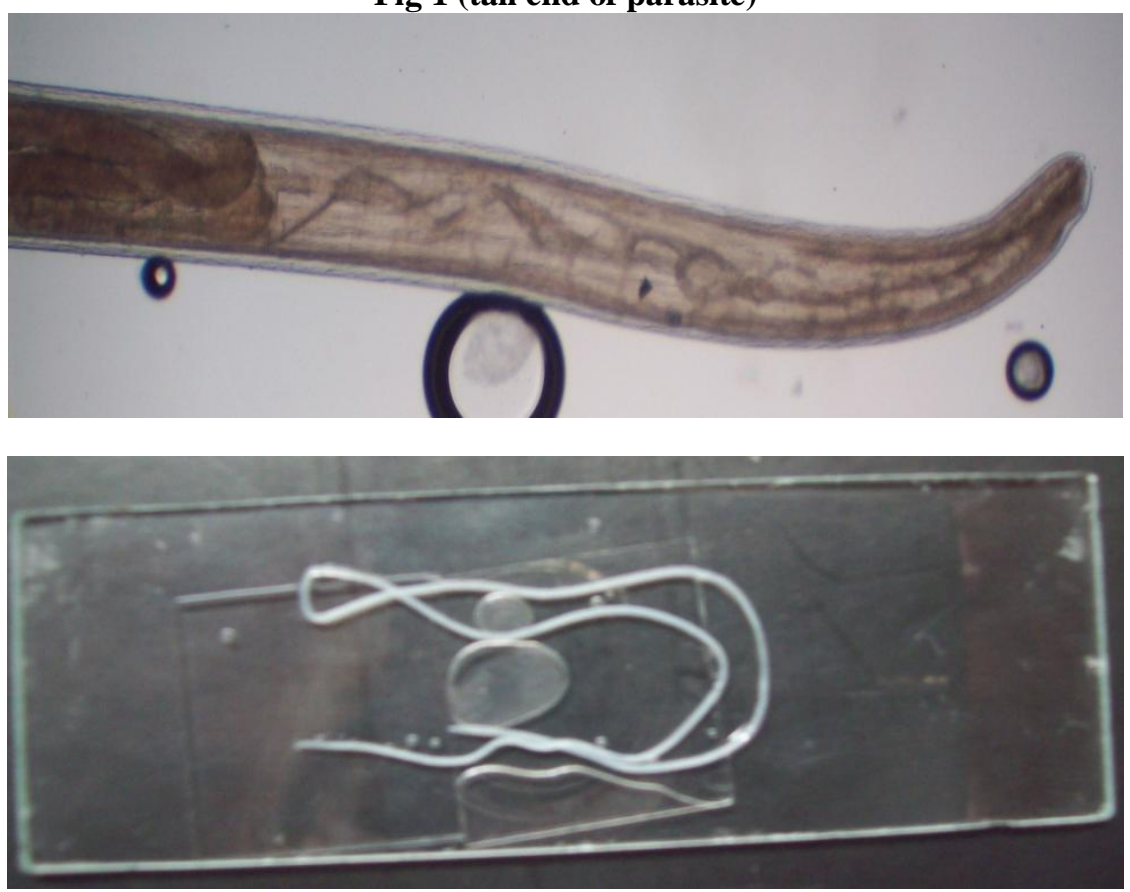

Fig 2 (gross features of parasite )

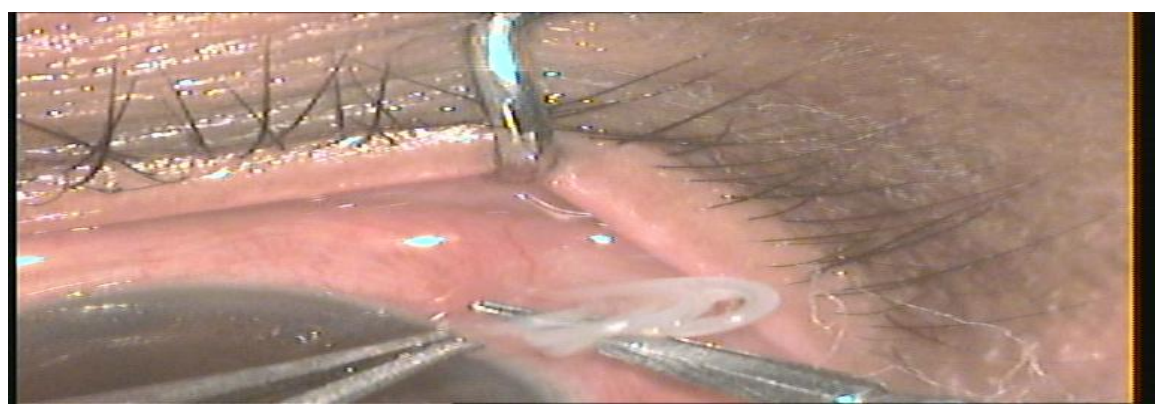

Fig 3(clinical picture )

Dr.Nancy Malla, Dr.Dipak Mendiratta

\section{Acknowledgement:}

Prof and Head ,Dept of parasitology ,PGI,Changdigarh.

Prof and Head ,Dept. of Microbiology ,MGIMS ,Sevagram, Wardha.

\section{References:}

[1] Mayank A Nanavaty, Ambarish J Nanavaty, Jitendra D Lakhani, Sucheta J bancroftian filarial worm Year : 2001, Volume : 49, Issue : 3 ,Page : 195-196

[2] World Health Organization. Lymphatic Filariasis: The Disease and its Control. Fifth report of the WHO Expert Committee on Filariasis. WHO Tech Rep Ser 1992;821.

[3] Rajesh Karyakarte ,Ajit Damle; Textbook of medical parasitology, $2^{\text {nd }}$ edition,2008. page -173-185.

[4] K.D.Chattergee; Textbook of parasitology ; $13^{\text {th }}$ edition ,2009.page- 236-258.

[5] Ganesh SK,Babu K,Kirshnakumar S Biswas J.Ocular filariasis due to Wuchereria bancrofti presenting as panuveitis: a case report;.Ocul Immunol Inflamm ;2003 June 11(2) 145-8, 